TAO, Vol. 15, No. 5, 901-923, December 2004

\title{
Water-soluble Ions of Aerosols in Taipei in Spring 2002
}

\author{
Shih-Chun Candice Lung ${ }^{1}{ }^{*}$, Chun-Hu Liu ${ }^{1}$, Shu-Yung Huang ${ }^{1}$, Tzu-Ju Lin ${ }^{1}$, \\ Charles C. K. Chou ${ }^{1}$, and Shaw Chen Liu ${ }^{1}$
}

(Manuscript received 15 July 2003, in final form 31 July 2004)

\begin{abstract}
Dust originating from arid and semiarid areas in Central Asia can reach Taiwan during springtime. However, aerosols in a metropolitan region, such as Taipei city, also have significant local sources. In this work, the influence of long-range transport and local pollution, on various water-soluble ions in fine and coarse modes, was investigated for several dust events. Concentration differences between dust-event and non-dust-event days were assessed. Field measurements were conducted in Taipei from February to May 2002. Twelve-hour samples of $\mathbf{P M}_{2.5}$ and $\mathbf{P M}_{10}$ were taken. Ion chromatography was used to analyze water-soluble ions $\left(\mathrm{Na}^{+}, \mathrm{NH}_{4}^{+}, \mathrm{K}^{+}, \mathrm{Mg}^{2+}\right.$, $\mathrm{Ca}^{2+}, \mathrm{Cl}^{-}, \mathrm{NO}_{3}{ }^{-}$, and $\left.\mathrm{SO}_{4}{ }^{2-}\right)$. The mean concentrations of $\mathrm{Na}^{+}, \mathrm{NH}_{4}^{+}$, $\mathrm{K}^{+}, \mathrm{Mg}^{2+}, \mathrm{Ca}^{2+}, \mathrm{Cl}^{-}, \mathrm{NO}_{3}^{-}, \mathrm{SO}_{4}{ }^{2-}$, and $\mathrm{PM}$ in the fine mode during the entire sampling campaign were $0.29,2.87,0.29,0.029,0.13,0.57,0.92,2.68$, and $28.2 \mu \mathrm{g} \mathrm{m}^{-3}$, respectively. The corresponding mean concentrations in the coarse mode $\left(\mathrm{PM}_{2.5-10}\right)$ were $0.75,0.30,0.096,0.14,0.63,0.84,2.33,1.60$, and 34.0 $\mu \mathrm{g} \mathrm{m}^{-3}$, respectively. Results of Principle Component Analysis showed that elevated concentrations of fine $\mathrm{Na}^{+}, \mathrm{K}^{+}, \mathrm{Mg}^{2+}, \mathrm{Ca}^{2+}$, and $\mathrm{Cl}^{-}$and coarse $\mathrm{Na}^{+}, \mathrm{Mg}^{2+}, \mathrm{Ca}^{2+}, \mathrm{NO}_{3}{ }^{-}$, and $\mathrm{SO}_{4}{ }^{2-}$ on dust-event days were a result of long-range transport. A prolonged influence of long-range transport on concentrations of fine and coarse ions, after dust peaked, was also observed. $\mathrm{K}^{+}, \mathrm{Mg}^{2+}$, and $\mathrm{Ca}^{2+}$ increased by about 1.7 to 3.8 fold and $\mathrm{Na}^{+}$and $\mathrm{Cl}^{-}$increased by $45-210 \%$ on dust-event days. Fine modes of $\mathrm{NH}_{4}{ }^{+}, \mathrm{NO}_{3}{ }^{-}$, and $\mathrm{SO}_{4}{ }^{2-}$ were derived from local pollution, while most coarse $\mathrm{NO}_{3}{ }^{-}$and some coarse $\mathrm{SO}_{4}{ }^{2-}$ were derived from long-range transport. On average, coarse $\mathrm{NO}_{3}{ }^{-}$and $\mathrm{SO}_{4}{ }^{2-}$ increased by $67 \%$ and $97 \%$, respectively, during dust events.
\end{abstract}

\footnotetext{
${ }^{1}$ Research Center for Environmental Changes, Academia Sinica, Taipei, Taiwan, ROC

* Corresponding author address: Dr. Shih-Chun Candice Lung, Research Center for Environmental Changes, Academia Sinica, Taiwan, ROC; E-mail: sclung@rcec.sinica.edu.tw
} 
(Key words: Asian dust, Water-soluble ion, Long-range transport, Local pollution)

\section{INTRODUCTION}

Asian dust storms (ADS) are common during late winter and spring in East Asia (e.g., Duce et al. 1980; Tsunogai and Kondo 1982; Prospero et al. 1989; Liu and Shiu 2001; Terada et al. 2002). They occur in arid and semi-arid regions during high-speed surface wind conditions (Duce et al. 1980). Under favorable synoptic conditions, significant amounts of Asian dust are transported to Taiwan (Chen \& Chen 1987; Liu and Shiu 2001). Young et al. (1997) reported that during a dust event in spring 1995, $\mathrm{PM}_{10}$ levels, at Taiwan Environmental Protection Administration (TEPA) monitoring stations, jumped dramatically within 3 - 4 hours, along the western side of Taiwan. The magnitude and timing of maximum $\mathrm{PM}_{10}$ levels tended to decrease and be delayed from north-to-south, coast-to-inland, and west-to-east. On the other hand, Young et al. (1997) also reported another high concentration case due to local pollution, only several days after the dust event. It was shown that the accumulation of $\mathrm{PM}_{10}$ and $\mathrm{CO}$ were due to stagnant weather conditions, and a shallow surface inversion layer, which was associated with the returning flow of a high-pressure system.

In recent years, ADS over Taiwan have received considerable attention because of their impact on air quality. High concentrations of mineral elements and high levels of anthropogenic species, such as sulfate and nitrate, have been observed in the outflow of continental Asia (Talbot et al. 1997; Matsumoto et al. 1998; Clarke et al. 2001). Anthropogenic aerosols have reached Korea (Park and Cho 1998), Japan (Ishikawa et al. 1998), Hawaii (Perry et al. 1999 ) and even western sections of the US mainland (Jaffe et al. 1999 \& 2003). It was estimated that the total emissions of $\mathrm{SO}_{2}$ and $\mathrm{NO}_{\mathrm{X}}$ from China in 1986 were 18.3 and $6.77 \mathrm{Tg} \mathrm{yr}^{-1}$, respectively (Kato \& Akimoto 1992). This trend is expected to increase due to rapid increases in energy consumption and economic activity in China. Thus, assessing the influence of transported anthropogenic aerosols on Taiwan is very important. Nonetheless, aerosols in metropolitan regions, such as Taipei, also have significant local sources. Whether the observed pollutants of dust-event days are from local sources or have been picked up and carried to Taiwan as a result of long-range transport is an important scientific question.

In this work, influences of long-range transport and local pollution on various watersoluble ions, in fine and coarse modes, on dust-event days in Taipei were investigated. Watersoluble $\mathrm{Na}^{+}, \mathrm{NH}_{4}{ }^{+}, \mathrm{K}^{+}, \mathrm{Mg}^{2+}, \mathrm{Ca}^{2+}, \mathrm{Cl}^{-}, \mathrm{NO}_{3}{ }^{-}$, and $\mathrm{SO}_{4}{ }^{2-}$ were analyzed and Principle Component Analysis (PCA) was used to differentiate between the contributions of long-range transport and local pollution. Concentration differences of water-soluble ions on dust-event and non-dust-event days were also evaluated.

\section{METHODS AND MATERIALS}

\subsection{Sampling Strategy}

Samplings of aerosols were conducted on the rooftop of the Central Weather Bureau 
located in central Taipei city. The sampling height was about 20 meters above ground. Twelvehour samples were taken from approximately 8 am to $8 \mathrm{pm}$ (daytime sample, D) and from $8 \mathrm{pm}$ to 8 am (night-time sample, N). From February to April 2002, sampling was conducted based on dust-event forecasts. Samples were collected one day before forecasted dust events and up until one day after the events had ceased. Since there were no dust storms in May 2002, samples were taken in the last week of the month.

One set of Partisol ${ }^{\circledR}$ Model 2300 Speciation Sampler (RP2300, Rupprecht \& Patashnick Co., Inc., Albany, NY, USA) was used to collect $\mathrm{PM}_{2.5}$ and $\mathrm{PM}_{10}$ samples. RP2300 consists of four channels, two of which were used to collect $\mathrm{PM}_{2.5}$ and $\mathrm{PM}_{10}$ samples, for elemental carbon/organic carbon (EC/OC) analysis. Two other channels were used to collect $\mathrm{PM}_{2.5}$ and $\mathrm{PM}_{10}$ samples, using $47 \mathrm{~mm}$ Teflon filters (P/N R2PL047, PALL Corporation, Ann Arbor, Michigan), followed by Nylon and citric-acid-coated quartz filters. After the samples were obtained, the Teflon filters were cut in half, for metal and ion analysis. Nylon and quartz filters were used to adsorb easily volatilized particulate nitrate and ammonium, respectively. In addition, RP2300 consists of honeycomb denuders that adsorb acidic gases to avoid artifacts in filter analysis. The results of EC/OC and metal analysis are presented in two accompanying papers (Chou et al. 2004; Hsu et al. 2004). A Gilian calibrator (Gilibrator 2, Sensioyne Gilian, Clearwater, FL) was used to calibrate flow rates of the four channels to approximately $101 \mathrm{~min}^{-1}$. These rates were then controlled by four independent mass flow controllers and a microprocessor ensuring constant volumetric flow rates.

\subsection{Extraction and Analysis}

Filters were equilibrated in a $20 \pm 1{ }^{\circ} \mathrm{C}$ and $35 \pm 5 \% \mathrm{RH}$ environment for 48 hours, before a Mettler micro-balance (MX5, Mettler-Toledo AG, Grelfensee, Switzerland) was used to weigh them. A Static Eliminator (Allfield Enterprise Corp., Taipei, Taiwan) was used to neutralize electrostatic charges, during weighing. Each filter was weighed twice, and the acceptable variation was $3 \mu \mathrm{g}$.

After weighing, 30 min sonication, with $4 \mathrm{cc}$ of de-ionized water, was used to extract the Teflon filters. AS12A and CS12A columns, with the conductivity detector of a Dionex DX120 Ion Chromatograph (Dionex Corporation, Sunnyvale, CA, USA), were used for anion and cation analysis, respectively. The eluent was $0.3 \mathrm{mM} \mathrm{NaHCO}$ and $2.7 \mathrm{mM} \mathrm{Na} \mathrm{CO}_{3}$ for anion and $16 \mathrm{mM} \mathrm{CH}_{4} \mathrm{O}_{3} \mathrm{~S}$ for cation analysis, with $1 \mathrm{ml} \mathrm{min}^{-1}$. The same method was used to extract and analyse Nylon and quartz filters.

Standards were purchased from Merck (Merck KgaA, Darmstadt, Germany) and sevenpoint calibration curves were prepared for each batch of samples. The r-values of calibration curves were all greater than 0.995 . Method detection limits (MDL) of ionic species, in $\mu \mathrm{g}$ per milliliter, were $\mathrm{Li}^{+} 0.084, \mathrm{Na}^{+} 0.091, \mathrm{NH}_{4}^{+} 0.083, \mathrm{~K}^{+} 0.123, \mathrm{Mg}^{2+} 0.007, \mathrm{Mn}^{2+} 0.017$, $\mathrm{Ca}^{2+}$ 0.143, $\mathrm{Sr}^{2+} 0.108, \mathrm{~F}^{-} 0.105, \mathrm{Cl}^{-} 0.044, \mathrm{NO}_{3}{ }^{-} 0.077, \mathrm{PO}_{4}{ }^{-} 0.104$, and $\mathrm{SO}_{4}{ }^{2-} 0.046$. Laboratory blanks were used to assess contamination. The blank concentrations of ionic species were less than corresponding MDLs. Concentrations of non-detects were taken as zero. Since concentrations of $\mathrm{Li}^{+}, \mathrm{Mn}^{2+}, \mathrm{Sr}^{2+}, \mathrm{F}^{-}$, and $\mathrm{PO}_{4}^{-}$were below detection limits $(0.005$, $0.005,0.025,0.01$, and $0.05 \mu \mathrm{g} \mathrm{ml}^{-1}$, respectively), for more than $90 \%$ of filters, they were not 
included in the following data analysis.

\subsection{Data Analysis}

Concentrations of ionic species in the coarse mode $\left(\mathrm{PM}_{2.5-10}\right)$ were obtained by subtracting those of $\mathrm{PM}_{2.5}$ (the fine mode) from the corresponding concentrations of $\mathrm{PM}_{10}$. The Statistical Analysis System (SAS version 8.2, SAS Institute Inc., Cary, NC) was used for statistical analysis. The Spearman correlation coefficients were used to assess associations between the two variables. The Wilcoxon rank-sum test was used to compare ionic concentrations of dust event days with those of non-dust event days. Principal Component Analysis (PCA) was used to determine if patterns of water-soluble ionic profiles, in fine and coarse modes, on days with dust events were different from days with no dust events. PCA has been used in environmental studies to extract information from multivariate datasets (Ozeki et al. 1995; Shine et al. 1995; Liu et al. 1996). The data was standardized beforehand to have zero mean and unit variance, so that certain ionic species, with high concentrations, would not affect PCA results. Only a component with eigen value greater than 1 accounts for a meaningful amount of variance, and is worthy of being retained. The retained components, with oblique rotation, were used in this study. A detailed description of PCA can be found in Kleinbaum et al. (1987).

\section{RESULTS}

\subsection{Concentration Distribution}

Sixty-three pairs of $\mathrm{PM}_{2.5} / \mathrm{PM}_{10}$ samples were collected: four in February, thirty-two in March, eighteen in April, and nine in May. Since the filters of one pair of samples, from February, were misplaced, during sampling, sixty-two pairs of valid samples were considered. The mean concentrations of $\mathrm{Na}^{+}, \mathrm{NH}_{4}^{+}, \mathrm{K}^{+}, \mathrm{Mg}^{2+}, \mathrm{Ca}^{2+}, \mathrm{Cl}^{-}, \mathrm{NO}_{3}{ }^{-}, \mathrm{SO}_{4}{ }^{2-}$, and $\mathrm{PM}$ in the fine mode, during the entire sampling campaign, were $0.29,2.87,0.29,0.029,0.13,0.57$, $0.92,2.68$, and $28.2 \mu \mathrm{g} \mathrm{m}^{-3}$, respectively. The corresponding mean concentrations in the coarse mode $\left(\mathrm{PM}_{2.5-10}\right)$ were $0.75,0.30,0.096,0.14,0.63,0.84,2.33,1.60$, and $34.0 \mu \mathrm{g} \mathrm{m}^{-3}$, respectively. On average, ionic species measured (summed as total ions) accounted for $45 \%$ of the fine particle mass and $25 \%$ of the coarse mass. Sulfate was the predominant ion $(28 \%)$ in the fine mode, while nitrate was the most significant ion $(9 \%)$ in the coarse mode. Detailed concentrations and percentages of each ionic species are listed in Table 1.

The time series of ionic concentrations in fine and coarse modes are shown in Figs. 1a - h. The coarse mode to fine mode ratios $(\mathrm{C} / \mathrm{F})$ of $\mathrm{PM}$ and various ionic species are also presented in Figs. 1a - h. The results indicate that $\mathrm{Na}^{+}, \mathrm{Mg}^{2+}, \mathrm{Ca}^{2+}, \mathrm{Cl}^{-}$, and $\mathrm{NO}_{3}^{-}$were mostly in coarse PM, while $\mathrm{NH}_{4}{ }^{+}, \mathrm{K}^{+}$, and $\mathrm{SO}_{4}{ }^{2-}$ were predominantly distributed in fine PM. In an accompanying paper, dust events were identified based on mass concentrations and $\mathrm{C} / \mathrm{F}$ ratios of $\mathrm{PM}$ and $\mathrm{Al}$ (Chou et al. 2004). Spearman correlation analysis was used to determine if $\mathrm{C} / \mathrm{F}$ ratios of various ions changed along with $\mathrm{C} / \mathrm{F}$ ratios of $\mathrm{PM}$. The results show that $\mathrm{C} / \mathrm{F}$ ratios of chloride and sulfate ions correlated with $\mathrm{C} / \mathrm{F}$ ratios of $\mathrm{PM}$ (Table 2). $\mathrm{C} / \mathrm{F}$ ratios of $\mathrm{Cl}^{-}$also 
Lung et al.

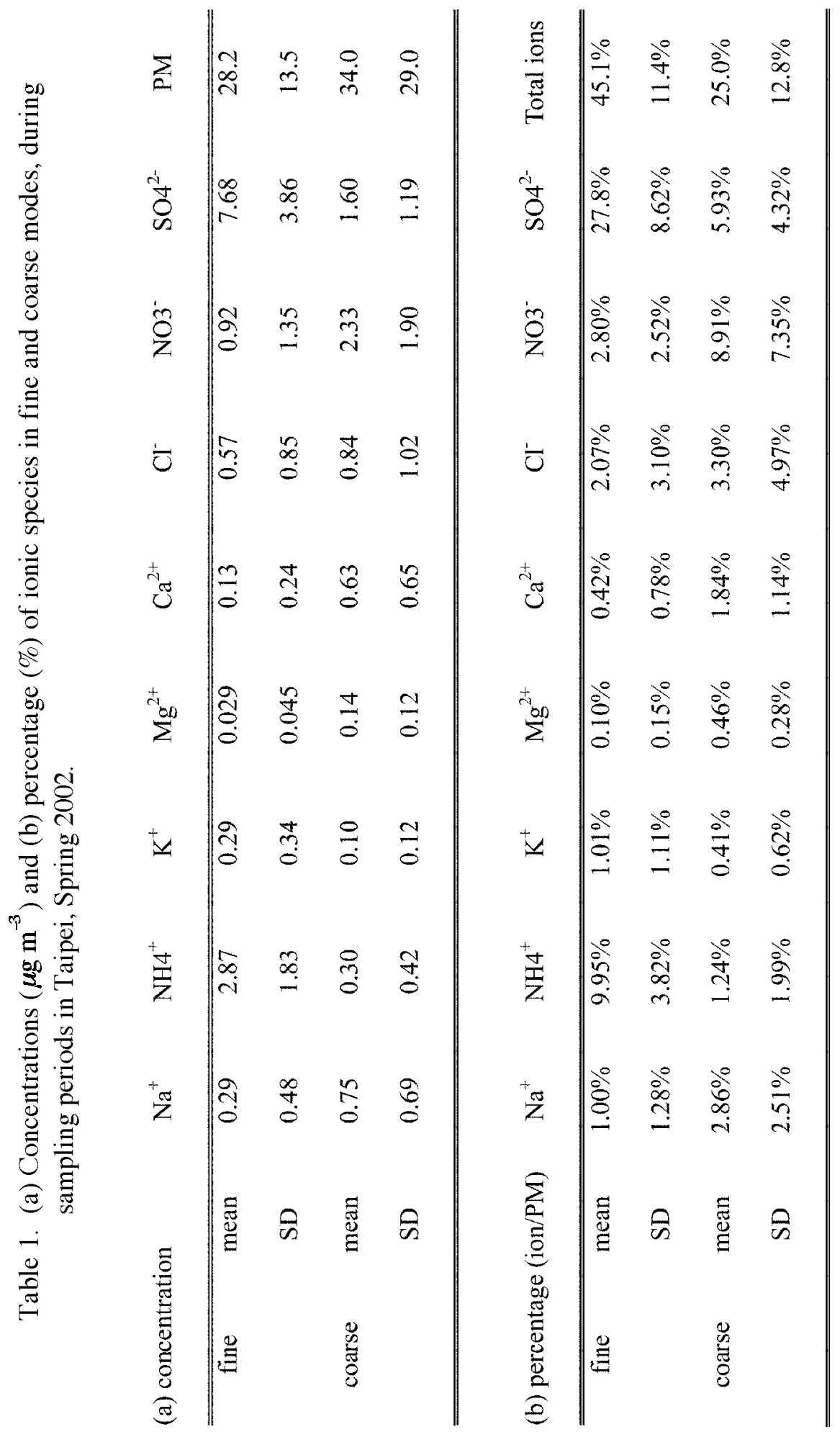


(a)

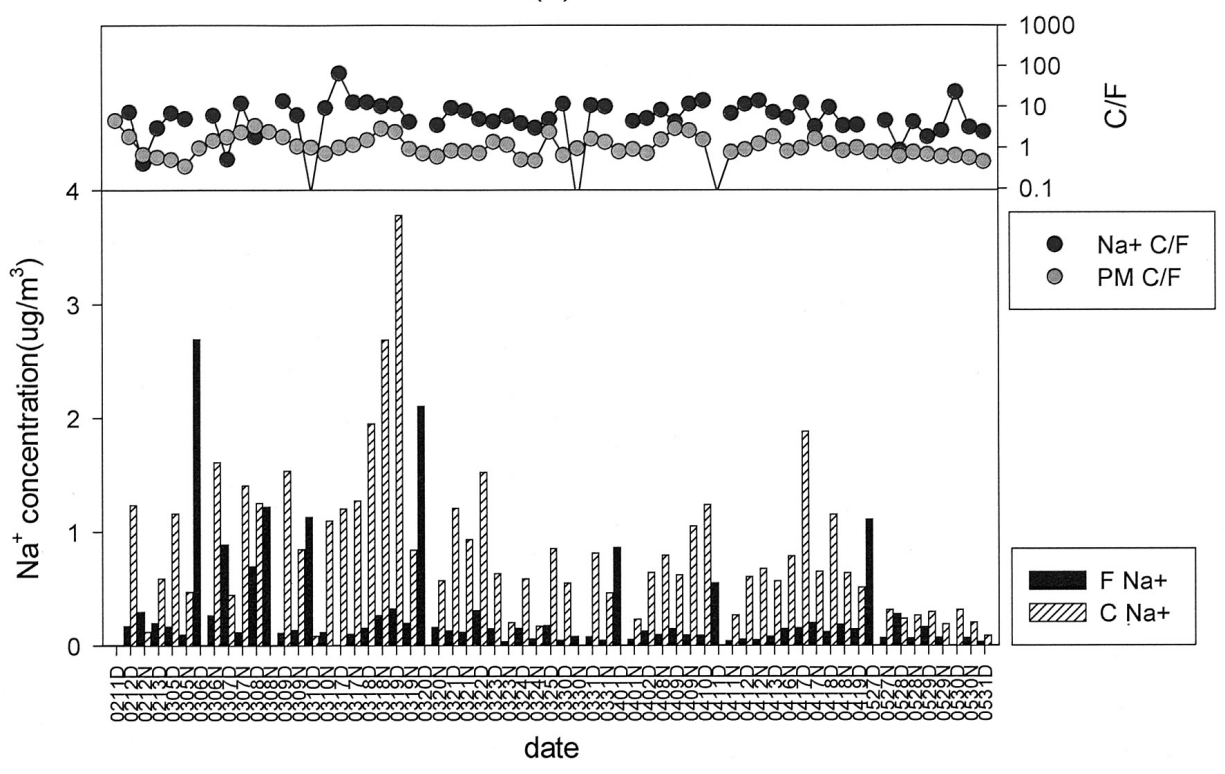

(b)



Fig. 1. Concentrations of (a) $\mathrm{Na}^{+}$, (b) $\mathrm{NH}_{4}{ }^{+}$, (c) $\mathrm{K}^{+}$, (d) $\mathrm{Mg}^{2+}$, (e) $\mathrm{Ca}^{2+}$, (f) $\mathrm{Cl}^{-}$, (g) $\mathrm{NO}_{3}{ }^{-}$, and (h) $\mathrm{SO}_{4}{ }^{2-}$ in fine and coarse modes and $\mathrm{C} / \mathrm{F}$ ratios of the corresponding ions and PM in Taipei, Spring 2002; F: fine mode, C: coarse mode; D: day samples, N: night samples. 
(c)

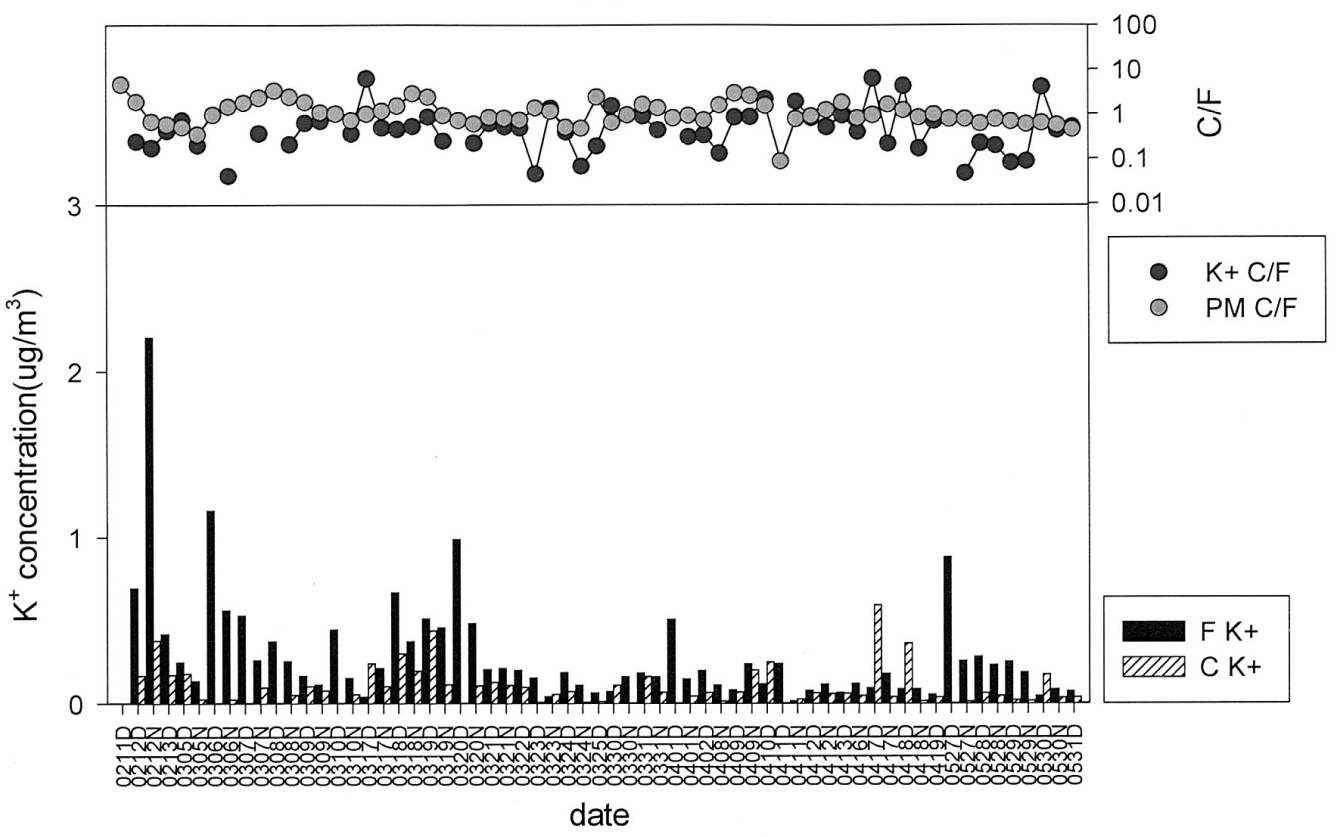

(d)

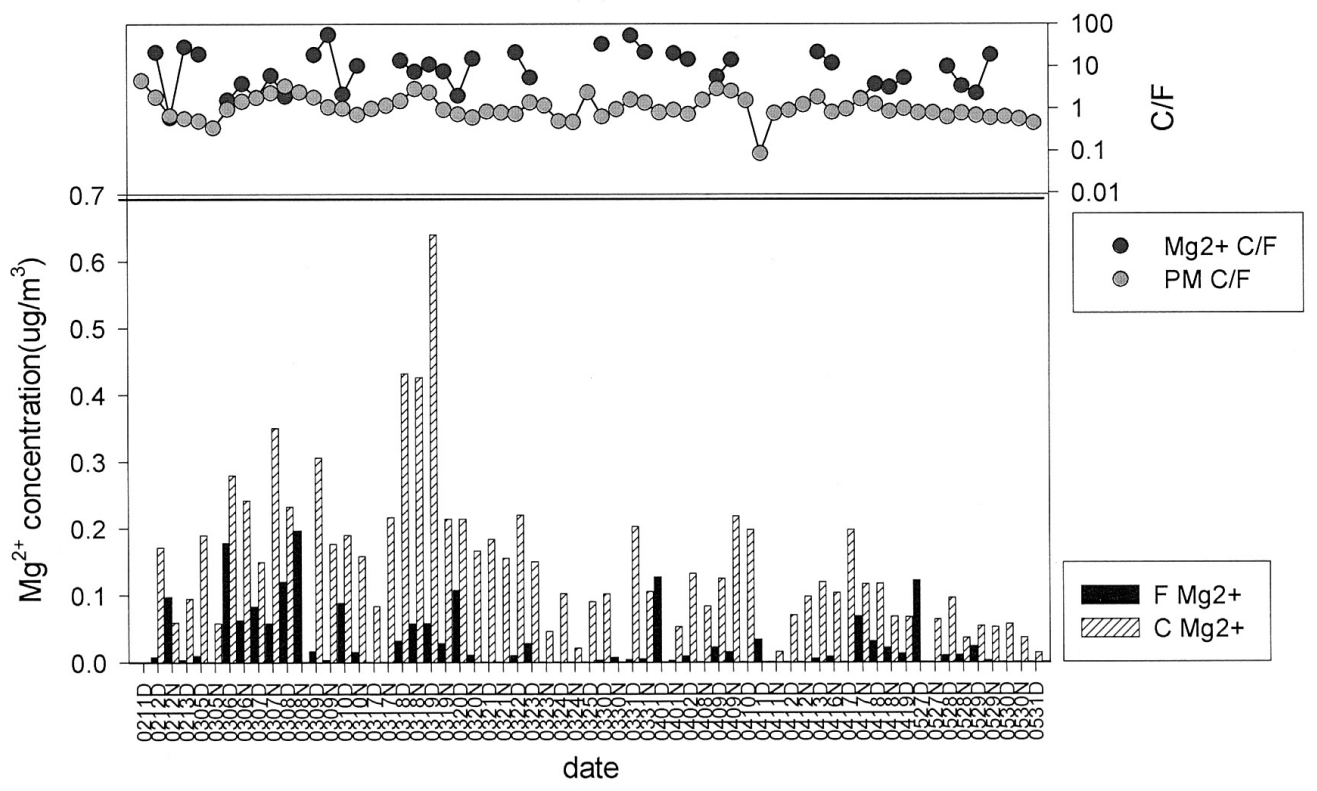

Fig. 1. Continued. 
(e)



(f)

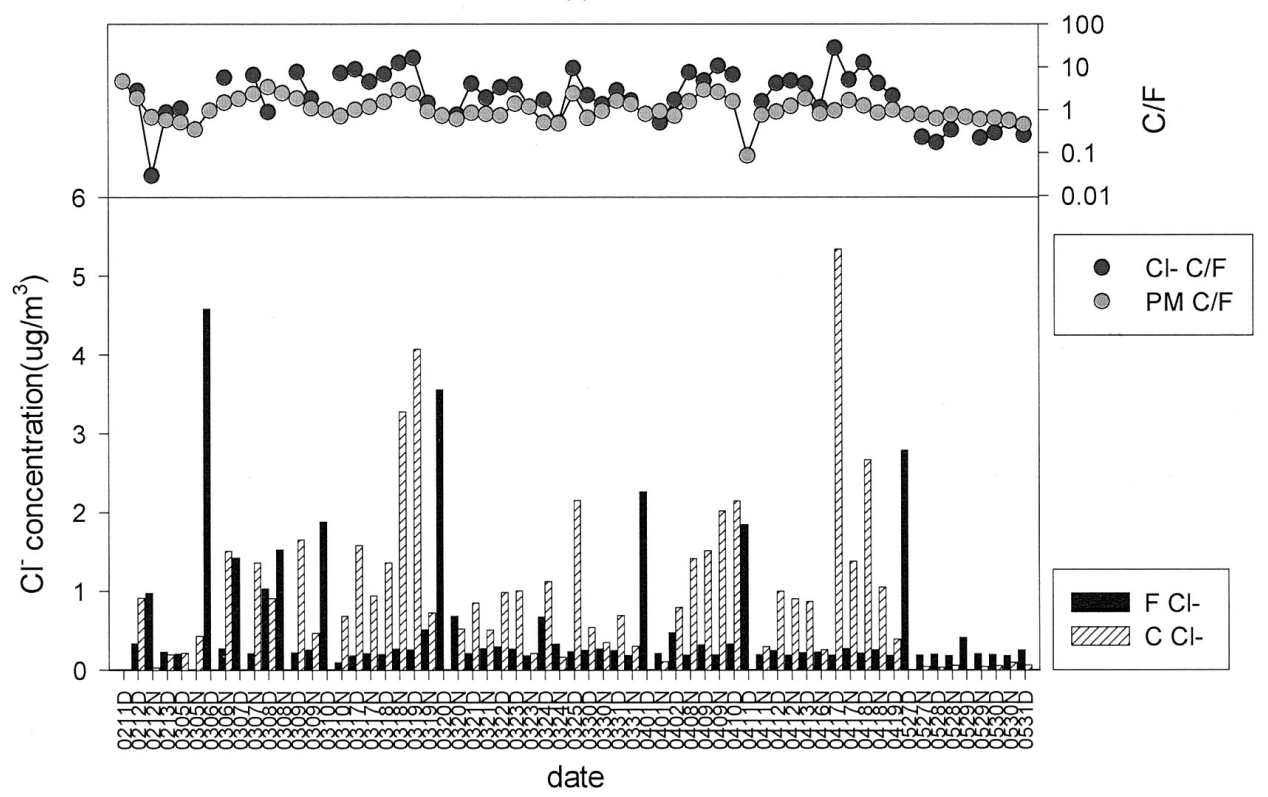

Fig. 1. Continued. 
(g)

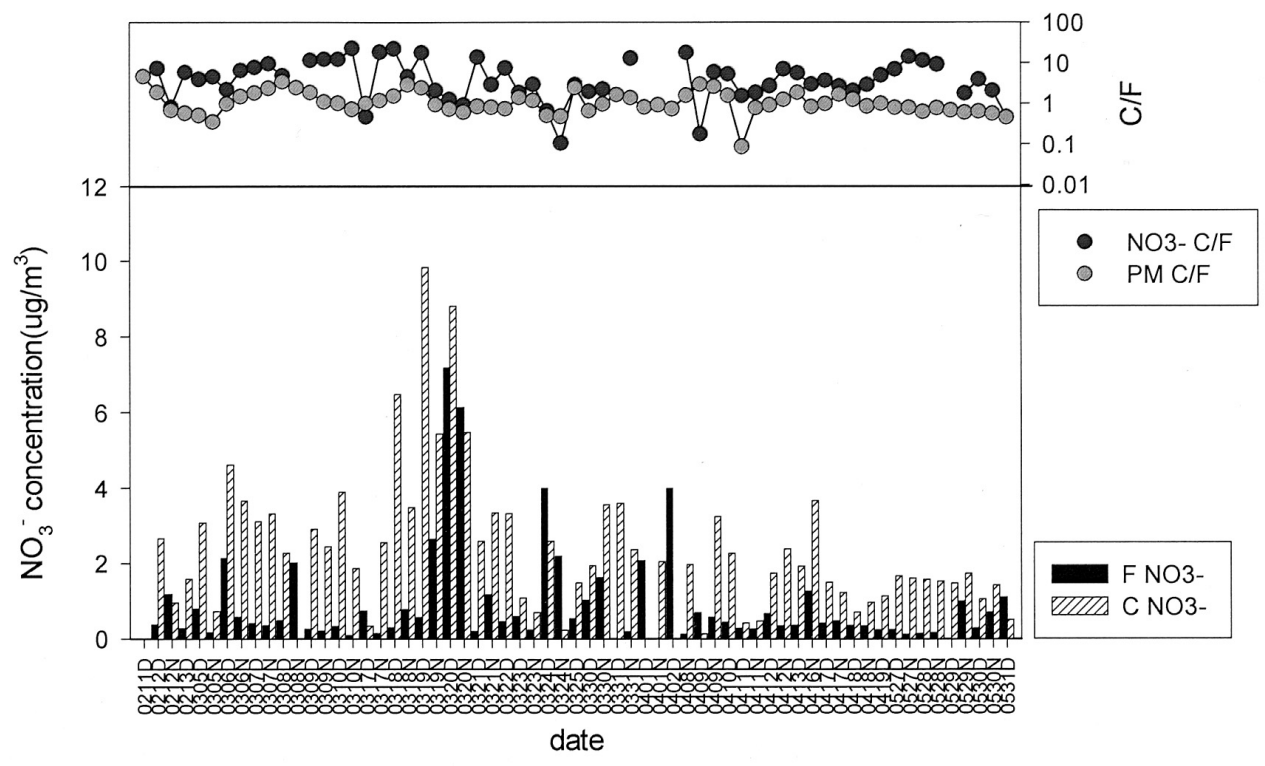

(h)

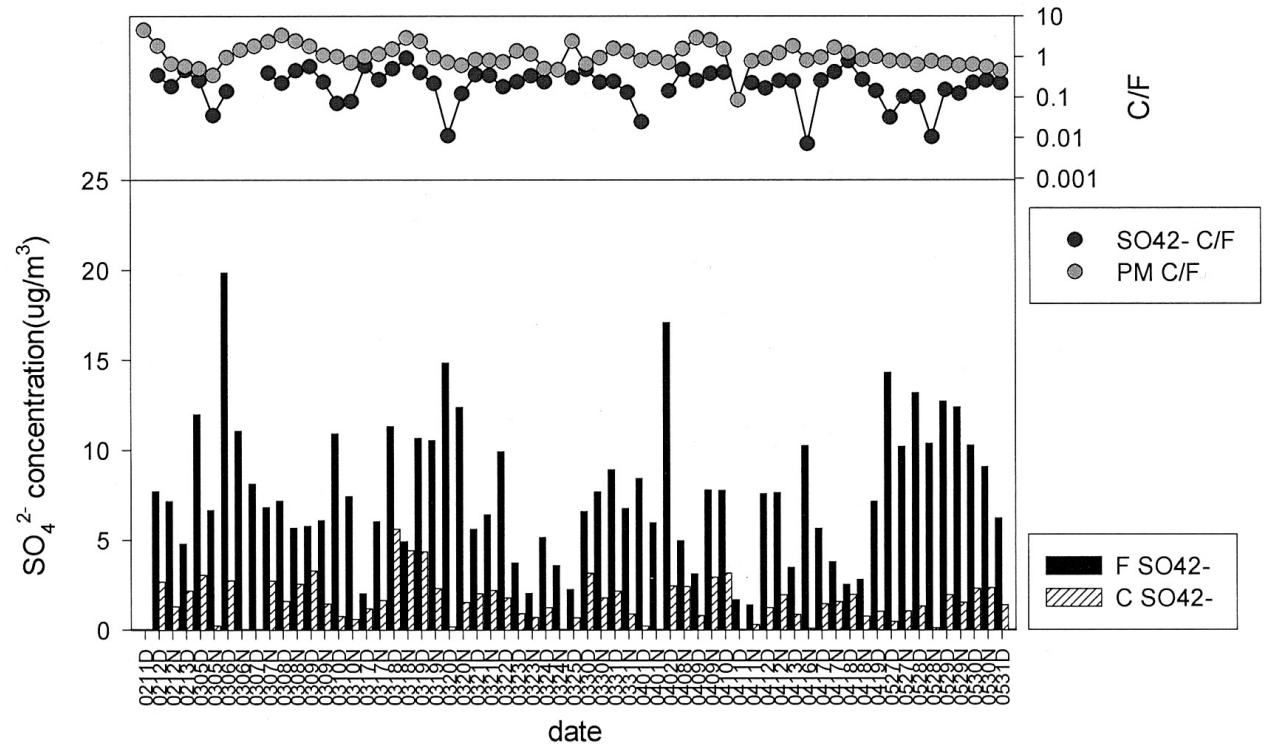

Fig. 1. Continued. 
correlated with $\mathrm{Na}^{+}, \mathrm{K}^{+}$, and $\mathrm{Ca}^{2+}$; and those of $\mathrm{SO}_{4}{ }^{2-}$ correlated with $\mathrm{Na}^{+}, \mathrm{K}^{+}$, and $\mathrm{Cl}^{-}$. In addition, $\mathrm{Na}^{+}, \mathrm{K}^{+}, \mathrm{Mg}^{2+}$, and $\mathrm{Ca}^{2+}$ inter-correlated. Since certain ions were predominantly distributed in the fine or coarse mode, $\mathrm{C} / \mathrm{F}$ ratios showed quite a few missing values (Figs. 1a - h). Hence, correlation coefficients obtained from C/F ratios might lead to an underestimate of the true association amongst ions and PM.

\subsection{Origins of Water-Soluble Ions}

In order to further assess the relationship of the ionic species, PCA was used to extract patterns of ionic profiles in fine and coarse modes, during the entire sampling period. The results show that only the first two and three components displayed eigen values greater than 1 for fine and coarse modes, respectively. Thus, these components were retained for rotation. Results of rotated component patterns are listed in Table 3. An ion was said to load on a given component if the factor loading for that component was 0.4 or greater. It should be noted that scattered precipitation was observed on several sampling days. PCA was conducted by excluding these days and the results were very similar to those in Table 3. Therefore, PCA results, based on all sampling days, were retained, to retain more information. Similarities between these two sets of PCA results also indicated the robustness of the data analysis method.

The first component of the fine mode was comprised of $\mathrm{Na}^{+}, \mathrm{K}^{+}, \mathrm{Mg}^{2+}, \mathrm{Ca}^{2+}$, and $\mathrm{Cl}^{-}$. These ions could have come from either seawater or soil. $\mathrm{Na}^{+}$was conventionally assumed to be entirely from seawater. Ratios of $\mathrm{K}^{+}, \mathrm{Mg}^{2+}, \mathrm{Ca}^{2+}$, and $\mathrm{Cl}^{-}$to $\mathrm{Na}^{+}$were compared to seawater composition (Table 4). Since, Table 4 shows that the ratios of $\mathrm{K}^{+}$and $\mathrm{Ca}^{2+}$ to $\mathrm{Na}^{+}$ were much higher than those in seawater, these ions must have had an additional source(s), such as soil. Ions from two distinct sources (seawater and soil) were both included in the first component, indicating that these ions were probably transported to Taipei, under the same synoptic meteorological conditions. Therefore, this component could be taken as an indicator of long-range transport. Since, the second component consisted of pollutants $\left(\mathrm{NH}_{4}{ }^{+}, \mathrm{NO}_{3}{ }^{-}\right.$, and $\mathrm{SO}_{4}{ }^{2-}$ ), it could be used to represent local pollution. The two components accounted for $59 \%$ and $18 \%$, of variance in the fine mode, respectively.

With respect to the coarse mode, the first component included ions mainly from sea-salt $\left(\mathrm{Na}^{+}\right)$, soil $\left(\mathrm{Mg}^{2+}, \mathrm{Ca}^{2+}\right)$ and anthropogenic $\left(\mathrm{NO}_{3}^{-}, \mathrm{SO}_{4}{ }^{2-}\right)$ sources. For the same reason as the fine mode, this component could be used as an indicator of long-range transport. This component showed that long-range transport not only brought mineral particles, but also carried anthropogenic aerosols to Taipei, at least in the coarse mode. Since, the second component mainly consisted of ions from sea-salt, it was used to represent the influence of sea-spray. The third component, similar to the second component for the fine mode, was viewed as an indication of local pollution. These three components could explain around 57\%, 16\%, and $13 \%$, of variance in the coarse mode, respectively.

According to the factor loading (Table 3), long-range transport would bring fine $\mathrm{Na}^{+}$, $\mathrm{K}^{+}, \mathrm{Mg}^{2+}, \mathrm{Ca}^{2+}$, and $\mathrm{Cl}^{-}$, and coarse $\mathrm{Na}^{+}, \mathrm{Mg}^{2+}, \mathrm{Ca}^{2+}, \mathrm{NO}_{3}{ }^{-}$, and $\mathrm{SO}_{4}{ }^{2-}$ to Taipei. Since the first principle component (PC1) of both fine and coarse modes represented long-range transport, a positive value of this $\mathrm{PC}$ indicated that concentrations, of the aforementioned ions for corresponding samples, were affected by long-range transport. Time series of $\mathrm{C} / \mathrm{F}$ ratios of 
Lung et al.

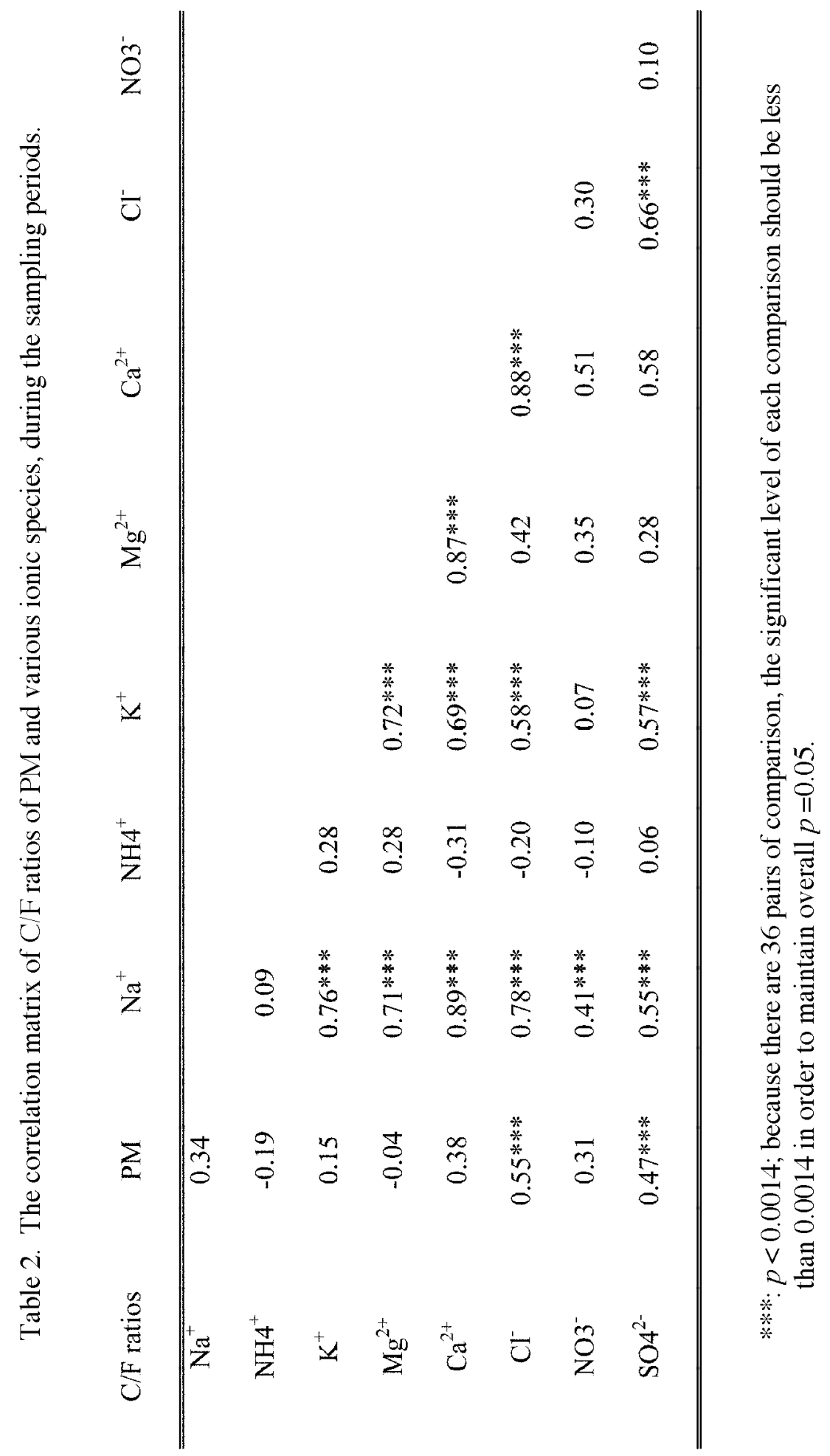


Table 3. Rotated component patterns from Principal Component Analysis of the (a) fine and (b) coarse mode.

(a) Ionic species Long-range transport Local pollution

\begin{tabular}{ccc}
\hline $\mathrm{Na}^{+}$ & $0.87^{*}$ & 0.15 \\
$\mathrm{NH} 4^{+}$ & -0.04 & $0.97^{*}$ \\
$\mathrm{~K}^{+}$ & $0.51^{*}$ & 0.32 \\
$\mathrm{Mg}^{2+}$ & $1.01^{*}$ & -0.13 \\
$\mathrm{Ca}^{2+}$ & $0.95^{*}$ & -0.09 \\
$\mathrm{Cl}^{-}$ & $0.85^{*}$ & 0.15 \\
$\mathrm{NO}^{-}$ & 0.05 & $0.71^{*}$ \\
$\mathrm{SO}^{2-}$ & 0.04 & $0.84^{*}$ \\
\hline \hline
\end{tabular}

(b) Ionic species Long-range transport Seasalt Local pollution

\begin{tabular}{cccc}
\hline \hline $\mathrm{Na}^{+}$ & $0.44^{*}$ & $0.61^{*}$ & -0.16 \\
$\mathrm{NH} 4^{+}$ & -0.03 & -0.05 & $0.95^{*}$ \\
$\mathrm{~K}^{+}$ & -0.17 & $0.98^{*}$ & 0.16 \\
$\mathrm{Mg}^{2+}$ & $0.86^{*}$ & 0.20 & -0.04 \\
$\mathrm{Ca}^{2+}$ & $0.84^{*}$ & 0.16 & -0.04 \\
$\mathrm{Cl}^{-}$ & -0.02 & $0.91^{*}$ & -0.2 \\
$\mathrm{NO}^{-}$ & $1.01^{*}$ & -0.3 & 0.04 \\
$\mathrm{SO}^{2-}$ & $0.40^{*}$ & $0.44^{*}$ & $0.47^{*}$ \\
\hline \hline
\end{tabular}

*: values greater than 0.4 . 
Table 4. Weight ratios of ionic species to $\mathrm{Na}^{+}$, during sampling periods in Taipei, Spring 2002.

\begin{tabular}{lcccccc} 
& & $\mathrm{K}^{+} / \mathrm{Na}^{+}$ & $\mathrm{Mg}^{2+} / \mathrm{Na}^{+}$ & $\mathrm{Ca}^{2+} / \mathrm{Na}^{+}$ & $\mathrm{Cl}^{-} / \mathrm{Na}^{+}$ & $\mathrm{SO}^{2-} / \mathrm{Na}^{+}$ \\
\hline \hline fine & mean & 1.65 & 0.09 & 0.33 & 2.78 & 73.1 \\
& $\mathrm{SD}$ & 1.25 & 0.10 & 0.51 & 2.22 & 97.1 \\
\multirow{2}{*}{ coarse } & mean & 0.18 & 0.22 & 0.96 & 0.98 & 13.1 \\
& $\mathrm{SD}$ & 0.41 & 0.29 & 1.13 & 0.69 & 76.1 \\
& & & & & & \\
seawater composition & 0.0371 & 0.120 & 0.0382 & 1.798 & 0.252 \\
\hline
\end{tabular}

Note: ionic ratios in seawater composition was obtained from Riley \& Chester (1971)

$\mathrm{PM}$ and the values of the first PC are shown in Figs. 2a, b. Four strong dust events (namely, $2 / 11 \mathrm{D}$ to $2 / 12 \mathrm{~N}, 3 / 6 \mathrm{D}$ to $3 / 9 \mathrm{~N}, 3 / 18 \mathrm{D}$ to $3 / 19 \mathrm{~N}$, and $4 / 8 \mathrm{~N}$ to $4 / 10 \mathrm{D}$ ) and two weak ones (3/ $23 \mathrm{D}-3 / 23 \mathrm{~N}$ and $4 / 17 \mathrm{~N}-4 / 18 \mathrm{D}$ ), during the sampling periods identified by Chou et al. (2004), are marked in the graph. For both fine and coarse modes, most samples of strong dust events had positive PC1 values, except for those of the fine mode in the fourth case (4/8N to 4/10D), which was relatively weak, in terms of its effects on water-soluble ions.

Five and eight measurements of fine and coarse modes, respectively, were found to have positive PC1 values, but were not from days identified as dust events (marked in the figures). In the fine mode, three out of the five "exceptions" occurred in samples taken directly after the dust events (case 2, 3, and 4). The spikes in the graph suggest that peaks of fine water-soluble ions, carried by long-range transport, arrived later than the mineral dusts. In fact, one spike was also observed at the end of Case 1 and just happened to be included in the dust event as the last sample. This spike again came later than the PM peak. The other two exceptions occurred on 4/01D and 5/27D and warranted further investigation. It should be noted that 3/31D-3/31N was a suspected dust case, and while it was discussed and excluded from dust-event cases by Chou et al. (2004), it was included as a dust case by Hsu et al. (2004). It was found here that the sample right after this suspected case (4/01D) showed a positive influence from long-range transport, as in the other strong dust-event cases, identified.

With regard to the coarse mode, one exception occurred on 3/31D, i.e., the suspected dust-event case, as stated above. One and five exceptions were found on the following days of Cases 2 and 3, respectively; thus indicating the prolonged influence of long-range transport. Moreover, the peak of PC1 in Cases 1, 3, and 4 occurred $12 \mathrm{hrs}$ after the peak of PM. This is consistent with the findings of Hsu et al. (2004), where peak values of Pb occurred 12 to $48 \mathrm{hrs}$, 


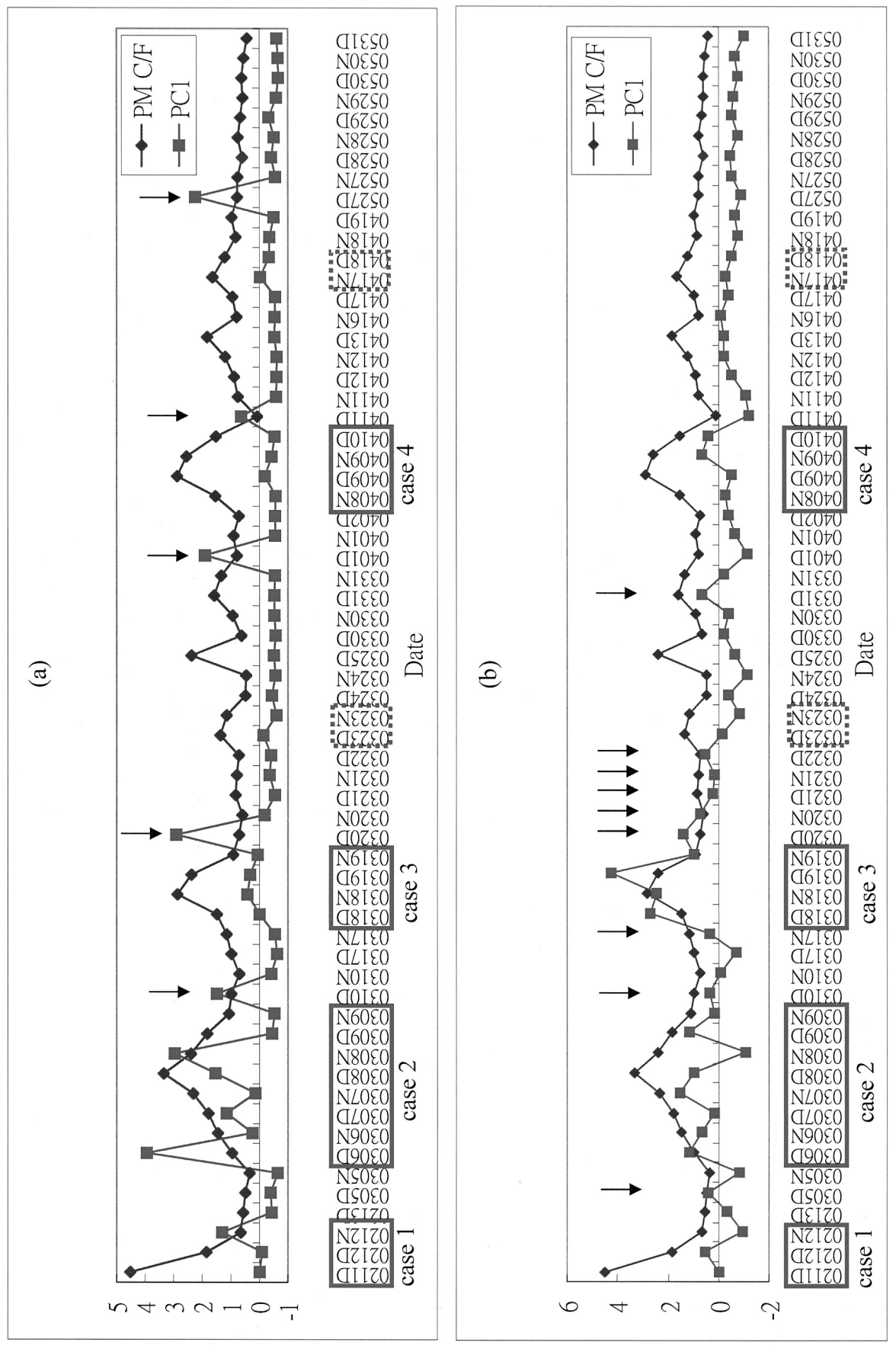

吾空

우은

$\sum_{1}^{n} \dot{n}$

之窝

อ를 छ

$\Xi \overline{0}$

的嘀

$\sum^{N}$

西

()ㅜㅇ

它

已苛

\#文

ఫิ

气要

용

$\frac{1}{1}$

월

클 울

吾

छั

¿ 80

过完

号苛苛

政

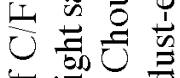

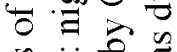

की

的总过



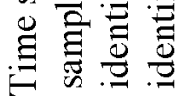

i

$\dot{8}$ 
after the dust peaks. Besides the prolonged effect, the other two exceptions in the coarse mode occurred 12 and 24 hrs, before dust-event Cases 3 and 2, respectively. In addition, the graph indicates that PC1, in both fine and coarse modes, varied during the dust events. These results were consistent with the findings of Talbot et al. (1997) and provided evidence that individual dust-laden air masses were not well mixed. Consequently, the arriving time of various particulate compounds varied. Lin et al. (2004) analyzed long-range transport cases from November 1999 to May 2000 and from November 2000 to May 2001, with hourly concentrations of air pollutants such as $\mathrm{PM}_{10}, \mathrm{CO}$, and $\mathrm{SO}_{2}$, from four EPA monitoring stations in Taiwan. They also pointed out that hourly correlations of mineral dust and air pollutants were very poor, as opposed to good correlations, based on seasonal variation, as observed by Prospero et al. (2003).

In general, identification of strong dust-event cases presented minor discrepancies between analysis, based on PM/Al, and those, based on long-range transport components, of water-soluble ions. Since, ADS carried mostly coarse PM and crustal elements such as Al, classification of dust-event days in this work complied with that of the four strong cases identified by Chou et al. (2004). Since, none of the weak dust-event days, identified by Chou et al. (2004), had positive PC1, only samples, from the four strong dust-event cases, were considered in the following data analysis, while other samples were viewed as non-dust-event samples.

\subsection{Comparison Between Dust-event and Non-dust-event Days}

Concentrations of water-soluble ions, in fine and coarse modes on dust-event and nondust-event days, are presented in Tables 5a, b. Non-sea-salt (nss) $\mathrm{SO}_{4}{ }^{2-}$ was calculated by excluding contributions of seawater. Ratios of dust-event to non-dust-event samples are also shown in Tables 5a, b. The Wilcoxon rank sum test was used to compare concentrations of the two periods. The significant differences, at $p=0.05$ and $p=0.1$, [the chances $(p)$ that these two groups came from the same population were less than 0.05 and 0.1 , respectively] are indicated in Table 5. Of all the ionic species in the fine and coarse modes, only concentrations of fine $\mathrm{NO}_{3}{ }^{-}$and coarse $\mathrm{NH}_{4}{ }^{+}$decreased during dust periods. They were both from local sources. $\mathrm{Mg}^{2+}$ and $\mathrm{Ca}^{2+}$ both increased by up to threefold, with most in both fine and coarse modes. $\mathrm{SO}_{4}{ }^{2-}$ and nss- $\mathrm{SO}_{4}{ }^{2-}$ in the fine mode (from local sources) were roughly the same in both periods; however, their concentrations in the coarse mode increased by about twofold during dust-event periods, due to long-range transport. $\mathrm{Na}^{+}$and $\mathrm{Cl}^{-}$in the coarse mode, presumably from seawater, increased by about twofold.

The percentages of water-soluble ions in fine and coarse PM, on dust-event and non-dustevent days, are tabulated in Tables $6 \mathrm{a}, \mathrm{b}$. Total ions accounted for about $45 \%$ of mass in $\mathrm{PM}_{2.5}$ and $27 \%$ in $\mathrm{PM}_{2.5-10}$ during non-dust-event days. During dust events, total ions had roughly the same percentage in the fine mode, although fine $\mathrm{K}^{+}, \mathrm{Mg}^{2+}$, and $\mathrm{Ca}^{2+}$ showed an obvious increase $(p<0.05)$ due to long-range transport. However, the percentage of total ions was reduced by about $25 \%$ in the coarse mode. This result was to be expected, since dust-laden air masses carry mostly mineral elements (Hsu et al. 2004). $\mathrm{Ca}^{2+}$ was the only ion in the coarse mode, which had a higher percentage during dust events, but the difference was not significant $(p>0.1)$. 


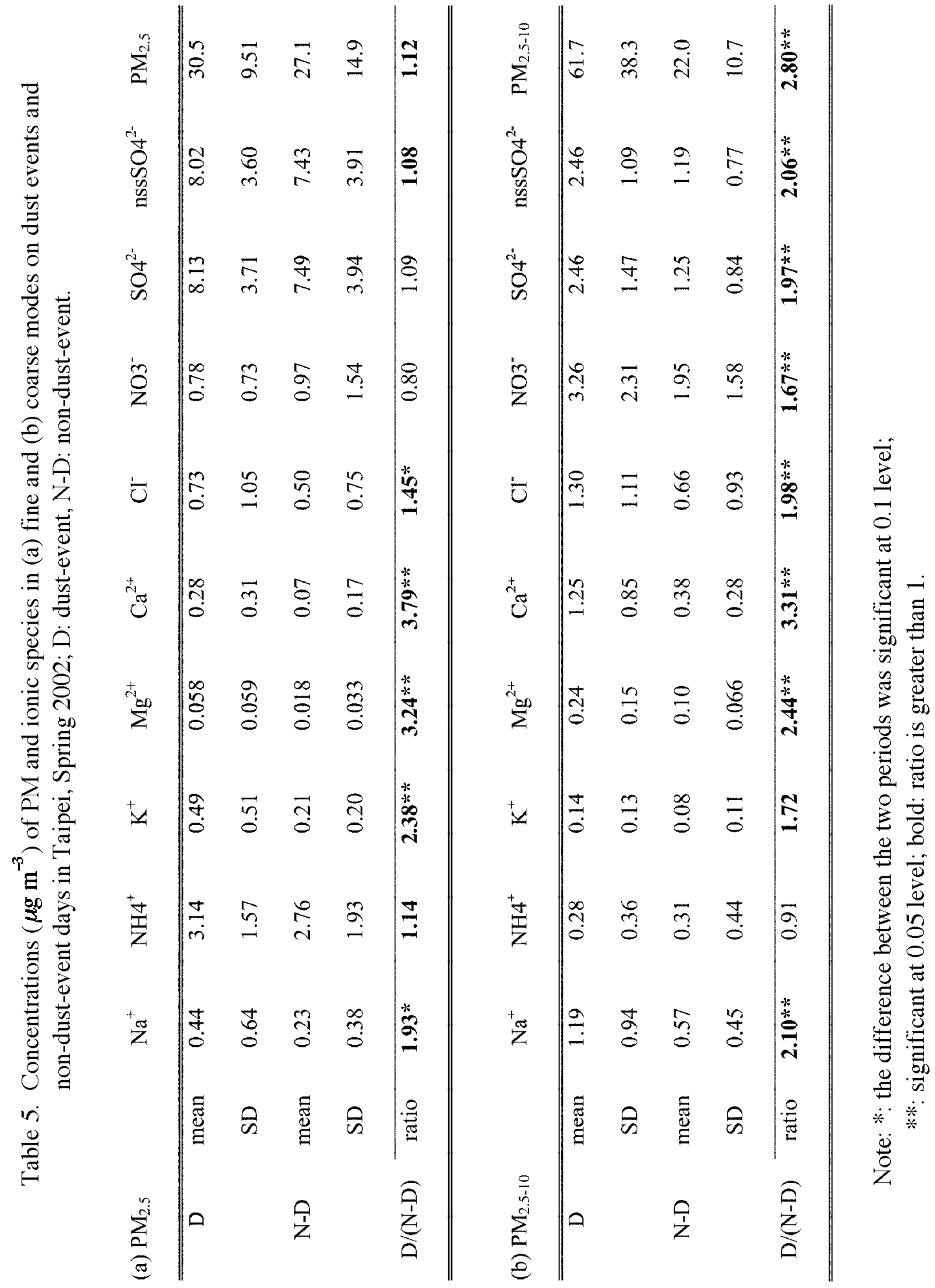




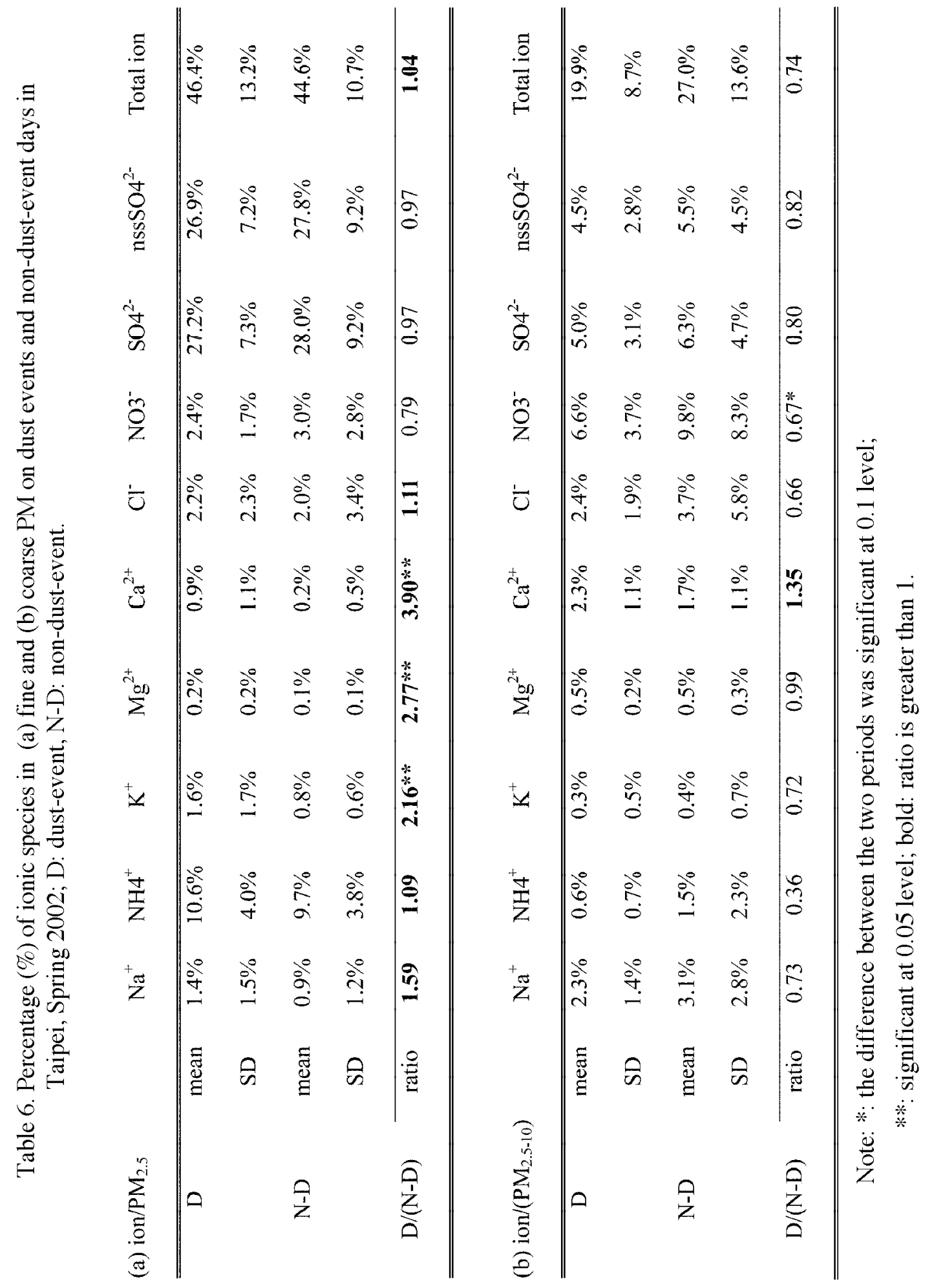


Equivalent ratios of various cations and anions are shown in Table 7. It should be kept in mind that, while hydrogen ions are an important component in the aerosol ion balance (Tanner et al. 1981), they were not measured. In both fine and coarse modes, equivalent ratios of total cations and total anions increased, during dust events $(p<0.1)$. This finding suggests that particulate matters in both fine and coarse modes were more alkaline on dust-event days, as expected. The ratios of $\mathrm{NH}_{4}{ }^{+}$to nss- $\mathrm{SO}_{4}{ }^{2-}, \mathrm{NO}_{3}{ }^{-}$, and the sum of $\mathrm{NO}_{3}{ }^{-}$and $\mathrm{SO}_{4}{ }^{2-}$, in the fine mode, were almost the same in both periods, but they were much lower in the coarse mode, during dust events. On the other hand, equivalent ratios of the sum of $\mathrm{Ca}^{2+}$ and $\mathrm{NH}_{4}{ }^{+}$ to the sum of nss- $\mathrm{SO}_{4}{ }^{2-}$ and $\mathrm{NO}_{3}{ }^{-}$increased in both fine and coarse modes, indicating that $\mathrm{Ca}^{2+}$ was a significant contributor to the ion balance, during dust events. This phenomenon was also observed on dust-event days in Hsinzhuang and Taichung in 2002 (Lin 2002; Ye 2002). The important role of Asian dust in the neutralization of acid rain was also observed in Japan (Ishikawa et al. 1998) and demonstrated with a numerical model (Terada et al. 2002).

Ratios of $\mathrm{Cl}^{-}$to sea-salt $\mathrm{Cl}^{-}$(ss Cl- $)$are shown in Table 7. $\mathrm{Cl}^{-}$depletion (\%) was defined as $100 \%$ minus $\mathrm{Cl}^{-} / \mathrm{ss} \mathrm{Cl}^{-}(\%)$. On average, $\mathrm{Cl}^{-}$depletion decreased during dust events; however, the change was not statistically significant. In the fine mode, almost all $\mathrm{Cl}^{-}$was from sea-salt on dust-event days, as the ratio was close to 1 . On non-dust-event days, higher percentages of $\mathrm{Cl}^{-}$over sea-salt $\mathrm{Cl}^{-}$indicated contributions from other sources. In the coarse mode, 41 - 47\% depletion was observed on dust-event and non-dust-event days.

\section{DISCUSSIONS}

$\mathrm{Nss} \mathrm{SO}_{4}{ }^{2-}$ is an important pollutant. Its concentrations in the fine mode were not much different between dust and non-dust periods, while those in the coarse mode showed a significant increase during dust periods. The same phenomenon was observed on dust-event days in Taichung in Spring 2002 (Ye 2002). The results of PCA show that fine $\mathrm{nss}^{-\mathrm{SO}_{4}}{ }^{2-}$ was from local sources, and coarse nss $\mathrm{SO}_{4}{ }^{2-}$ was partly affected by long-range transport, on dust-event days. Based on equivalent ratios, it was found that fine nss- $\mathrm{SO}_{4}{ }^{2-}$ was mostly in the form of $\left(\mathrm{NH}_{4}\right)_{2} \mathrm{SO}_{4}$ and $\mathrm{NH}_{4} \mathrm{HSO}_{4}$, while coarse nss- $\mathrm{SO}_{4}{ }^{2-}$ would be present in at least three forms, during dust events: $\left(\mathrm{NH}_{4}\right)_{2} \mathrm{SO}_{4}, \mathrm{NH}_{4} \mathrm{HSO}_{4}$, and $\mathrm{CaSO}_{4}$.

In ambient air, fine nss $\mathrm{SO}_{4}{ }^{2-}$ is mostly generated by condensation of $\mathrm{H}_{2} \mathrm{SO}_{4}$ on preexisting particles, followed by transitions to $\left(\mathrm{NH}_{4}\right)_{2} \mathrm{SO}_{4}$ and/or $\mathrm{NH}_{4} \mathrm{HSO}_{4}$, through reactions with gaseous $\mathrm{NH}_{3}$. The coarse sulfate was probably due to reactions of acidic gases, such as $\mathrm{H}_{2} \mathrm{SO}_{4}$ and $\mathrm{SO}_{2}$, with dust or sea salt particles (Sievering et al. 1992; Chameides and Stelson 1992). Ma et al. (2001) examined single particles, using Scanning Electron Microscope (SEM) coupled with an energy dispersive X-ray microanalyzer (EDX), and found that almost all of the single particles, sampled on ADS days, contained sulfur and chlorine. This result indicated that $S$ was released into the atmosphere in gaseous form and deposited onto coarse sea-salt particles, to form sulfuric acid during long-range transport. In addition, the simulation results, of a three-dimensional regional-scale atmospheric chemistry model, showed that chemical conversions of $\mathrm{SO}_{2}$ to sulfate, in the presence of mineral aerosols, may contribute $20-40 \%$ of total sulfate production (Xiao et al. 1997). Thus, increases in coarse sulfate 
concentrations, observed on dust-event days in Taipei, were probably due to acidic gases from the Asian continent, which reacted with coarse sea-salt and soil particles, during transport.

As for $\mathrm{NO}_{3}{ }^{-}$, which is another important pollutant, concentrations in the fine mode were reduced on dust-event days, while concentrations in the coarse mode increased significantly,

Table 7. Equivalent ratios of various cations and anions and percentage of $\mathrm{Cl}^{-}$compared to sea-salt (ss) $\mathrm{Cl}^{-}$(\%), on dust events and non-dustevent days in Taipei, Spring 2002; D: dust-event, N-D: non-dust-event.

\begin{tabular}{cccccccc} 
& & cation/ & $\mathrm{NH}_{4}^{+} /$ & $\mathrm{NH}_{4}^{+} /$ & $\mathrm{NH}_{4}^{+} /$ & $\left(\mathrm{Ca}^{2+}+\mathrm{NH}_{4}^{+}\right) /$ & $\mathrm{Cl}^{+} / \mathrm{ssCl}^{-}$ \\
(a) $\mathrm{PM}_{2.5}$ & & anion & nssSO4 $4^{2-}$ & $\mathrm{NO}_{3}^{-}$ & $\left(\mathrm{nssS}^{2-}+\mathrm{NO}_{3}{ }^{-}\right)$ & $\left(\mathrm{nssSO} 4^{2-}+\mathrm{NO}_{3}{ }^{-}\right)$ & $(\%)$ \\
\hline \hline $\mathrm{D}$ & mean & 1.10 & 1.03 & 23.01 & 0.96 & 1.04 & $104 \%$ \\
& $\mathrm{SD}$ & 0.28 & 0.27 & 16.25 & 0.25 & 0.26 & $42 \%$ \\
$\mathrm{~N}-\mathrm{D}$ & mean & 0.92 & 0.99 & 24.97 & 0.88 & 0.91 & $174 \%$ \\
& SD & 0.37 & 0.46 & 28.25 & 0.38 & 0.38 & $141 \%$ \\
\cline { 3 - 8 } $\mathrm{D} /(\mathrm{N}-\mathrm{D})$ & ratio & $\mathbf{1 . 2 0 *}$ & $\mathbf{1 . 0 4}$ & 0.92 & $\mathbf{1 . 0 8}$ & $\mathbf{1 . 1 5}$ & 0.60 \\
\hline
\end{tabular}

cation $/ \quad \mathrm{NH}_{4}^{+} / \quad \mathrm{NH}_{4}^{+} / \quad \mathrm{NH}_{4}^{+} /\left(\right.$nssSO $44^{2-} \quad\left(\mathrm{Ca}^{2+}+\mathrm{NH}_{4}^{+}\right) / \quad \mathrm{Cl}^{-} / \mathrm{ssCl}^{-}$

(b) $\mathrm{PM}_{2.5-10} \quad$ anion $\quad$ nssSO4 $\left.4^{2-} \quad \mathrm{NO}_{3}^{-} \quad \mathrm{NO}_{3}^{-}\right) \quad\left(\mathrm{nssSO}^{-2-}+\mathrm{NO}_{3}{ }^{-}\right) \quad(\%)$

\begin{tabular}{cccccccc}
\hline $\mathrm{D}$ & mean & 1.11 & 0.29 & 0.23 & 0.17 & 0.88 & $59 \%$ \\
& $\mathrm{SD}$ & 0.30 & 0.38 & 0.35 & 0.24 & 0.47 & $36 \%$ \\
$\mathrm{~N}-\mathrm{D}$ & mean & 1.07 & 0.86 & 0.75 & 0.35 & 0.76 & $53 \%$ \\
& $\mathrm{SD}$ & 0.86 & 1.45 & 1.60 & 0.56 & 0.91 & $40 \%$ \\
\cline { 2 - 7 } $\mathrm{D} /(\mathrm{N}-\mathrm{D})$ & ratio & $\mathbf{1 . 0 3 *}$ & 0.34 & 0.31 & 0.48 & $\mathbf{1 . 1 5 * *}$ & $\mathbf{1 . 1 2}$ \\
\hline \hline
\end{tabular}

Note: *: the difference between the two periods was significant at 0.1 level; **: significant at 0.05 level. 
during dust events. This behavior was also observed on dust-event days in Taichung in Spring 2002 (Ye 2002). PCA results revealed that fine $\mathrm{NO}_{3}{ }^{-}$was mainly derived from local pollution, while coarse $\mathrm{NO}_{3}{ }^{-}$was from long-range transport, during dust events. Atmospheric nitrate is formed by the transportation of gaseous nitric acid (or alternatively of $\mathrm{NO}_{2}, \mathrm{NO}_{3}$, or $\mathrm{N}_{2} \mathrm{O}_{5}$ ) to the particle surface and its subsequent reaction with other gases or particulate compounds. Fine particulate nitrate is mostly formed by a reaction between nitric acid and ammonia vapor, on particle surfaces, to give $\mathrm{NH}_{4} \mathrm{NO}_{3}(\mathrm{~s}$, aq). This reaction requires low temperatures and an abundant amount of $\mathrm{NH}_{3}$, more than is necessary to neutralize $\mathrm{H}_{2} \mathrm{SO}_{4}$ particles (Matsumoto and Tanaka 1996). Atmospheric coarse nitrate can be formed by heterogeneous reactions, between $\mathrm{HNO}_{3}(\mathrm{~g})$ and $\mathrm{NaCl}(\mathrm{s}, \mathrm{aq})$, on the surface of sea-salt particles. While particulate $\mathrm{NaNO}_{3}$ is relatively non-volatile, $\mathrm{NH}_{4} \mathrm{NO}_{3}$ may be converted back to gas. Released particulate $\mathrm{NH}_{4} \mathrm{NO}_{3}$ may be dissociated to gaseous $\mathrm{HNO}_{3}$, which in turn may be transferred to the coarse mode, through reactions with sea-salt particles, during transport over the ocean (Matsumoto et al. 1998; Zhuang et al. 1999). On dust-event days in Taipei, mean $\mathrm{NO}_{\mathrm{X}}$ concentrations obtained from Guting station, which is located $1.35 \mathrm{~km}$ from the CWB sampling site, were $36 \mathrm{ppm}$ compared to $43 \mathrm{ppm}$, on non-dust-event days. Less fine nitrate was observed, during dust events in Taipei, and was probably due to smaller $\mathrm{NO}_{\mathrm{x}}$. On the other hand, elevated coarse particulate nitrate was probably produced during transportation, by heterogeneous reactions of $\mathrm{HNO}_{3}(\mathrm{~g})$ (from the Asian Continent), on the surface of sea-salt and soil particles.

Concentrations of $\mathrm{NH}_{4}{ }^{+}$changed slightly on dust-event days, but the changes were not statistically significant. PCA results show that both fine and coarse $\mathrm{NH}_{4}{ }^{+}$were from local pollution. $\mathrm{NH}_{4}{ }^{+}$is mainly produced by reactions between gaseous $\mathrm{NH}_{3}$ and acidic sulfate particles. Dust carrying more alkaline coarse particles might prevent these reactions. Decreases in coarse $\mathrm{NH}_{4}{ }^{+}$concentration, during the four strong dust-event cases in Taipei, were insignificant.

$\mathrm{Na}^{+}$and $\mathrm{Cl}^{-}$ions are the main composition of seawater. Concentrations in both fine and coarse $\mathrm{Na}^{+}$were increased by about twofold on dust-event days. Since, dust-laden air masses need to pass over the ocean before reaching Taiwan, higher concentrations of $\mathrm{Na}^{+}$on dustevent days were anticipated. Concentrations of fine and coarse $\mathrm{Cl}^{-}$were also increased by 1.5 to 2 fold, during dust periods. Comparisons with seawater composition showed that $\mathrm{Cl}^{-}$ depletion occurred in the coarse mode. Since reactions of $\mathrm{NaCl}$, of sea-salt particles (mostly in the coarse mode), and acidic gases such as $\mathrm{SO}_{2}$ and $\mathrm{NO}_{\mathrm{X}}$, during transport, can cause chlorine depletion (Sinvering et al. 1992; Kerminen et al. 1997, Zhuang et al. 1999), it was not surprising to see the depletion of coarse $\mathrm{Cl}^{-}$.

With regard to $\mathrm{K}^{+}, \mathrm{Mg}^{2+}$, and $\mathrm{Ca}^{2+}$, concentrations, in both fine and coarse modes, increased during dust events. In addition, $\mathrm{C} / \mathrm{F}$ ratios of $\mathrm{K}^{+}, \mathrm{Mg}^{2+}$, and $\mathrm{Ca}^{2+}$ were correlated with the $\mathrm{C} / \mathrm{F}$ ratio of $\mathrm{Na}^{+}$. The results of PCA showed that $\mathrm{K}^{+}, \mathrm{Mg}^{2+}$, and $\mathrm{Ca}^{2+}$ of dust-event days, were mainly from long-range transport. Since $\mathrm{K}^{+}, \mathrm{Mg}^{2+}$, and $\mathrm{Ca}^{2+}$ are important crustal elements of Asian dust, this result was to be expected. The increase of these three elements was also observed in Taichung on dust-event days in 2002 (Ye 2002). 


\section{CONCLUSION}

In summary, all water-soluble ions, in both fine and coarse modes, increased on dustevent days, in Taipei in Spring 2002, except for fine $\mathrm{NO}_{3}{ }^{-}$and coarse $\mathrm{NH}_{4}{ }^{+}$. PCA was used to differentiate the influences of long-range transport from that of local pollution. This analysis showed that long-range transport brought fine $\mathrm{Na}^{+}, \mathrm{K}^{+}, \mathrm{Mg}^{2+}, \mathrm{Ca}^{2+}$, and $\mathrm{Cl}^{-}$as well as coarse $\mathrm{Na}^{+}, \mathrm{Mg}^{2+}, \mathrm{Ca}^{2+}, \mathrm{NO}_{3}^{-}$, and $\mathrm{SO}_{4}{ }^{2-}$ to Taipei, while the fine/coarse $\mathrm{NH}_{4}{ }^{+}$, fine $\mathrm{NO}_{3}{ }^{-}$, and fine $\mathrm{SO}_{4}{ }^{2-}$ were mostly from local sources. On dust-event days, sea-salt indicators, $\mathrm{Na}^{+}$and $\mathrm{Cl}^{-}$, increased by about twofold. Crust elements, such as $\mathrm{K}^{+}, \mathrm{Mg}^{2+}$, and $\mathrm{Ca}^{2+}$, increased by about 1.7 to 3.8 fold, during dust events. With regard to pollutants, coarse particulate sulfate and nitrate increased by about $97 \%$ and 67\%, respectively, and long-range transport affected both.

This study demonstrated that during dust events in springtime, anthropogenic aerosols, such as coarse sulfate and nitrate, from the Asian continent, could be transported to Taipei. This work also showed, however, that the majority of fine nitrate and sulfate, which are responsible for certain irritating effects on respiratory tracts, were mostly from local pollution sources.

Acknowledgement Academia Sinica Theme Project (Project number: 33, 2002) and Bureau of Environmental Monitoring and Data Processing, Environmental Protection Administration, Taiwan, R.O.C. (grant EPA-88-FA34-03-2001) supported this project. The authors are solely responsible for the contents of this study and the views expressed herein do not necessarily represent the official views of the EPA.

\section{REFERENCE}

Chameides, W. L., and A. W. Stelson, 1992: Aqueous-phase chemical processes in deliquescent sea-salt aerosols: a mechanism that atmospheric cycles of $\mathrm{S}$ and sea salt.J. Geophys. Res., 97, 20565-20580.

Chen, T. J., and H. J. Chen, 1987: Study on large-scale features of dust storm system.Meteor. Res., 10, 57-80.

Chou, C. C. K., C. Y. Lin, T. K. Chen, S. C. C. Lung, S. C. Hsu, S. C. Liu, and C. Y. Young, 2004: Influence of long-range transported dust particles on local air quality: A case study on Asian dust episodes in Taipei during the spring of 2002.TAO, 15, 881-899.

Clarke, A. D., W. G. Collins, P. J. Rasch, V. N. Kapustin, K. Moore, S. Howell, and H. E. Fuelberg, 2001: Dust and pollution transport on global scales: Aerosol measurements and modek predictions. J. Geophys. Res., 106, 32555-32569.

Duce, R. A., C. K. Unni, B. J. Ray, J. M. Prospero, and J. T. Merrill, 1980: Long-Range Atmospheric Transport of Soil Dust from Asia to the Tropical North Pacific: Temporal Variability. Science, 209, 1522-1524. 
Hsu, S. C., S. C. Liu, C. Y. Lin, R. T. Hsu, Y. T. Huang, and Y. W. Chen, 2004: Metal Compositions of $\mathrm{PM}_{10}$ and $\mathrm{PM}_{2.5}$ Aerosols in Taipei during Spring, 2002.TAO, 15, 925-948.

Ishikawa, Y., K. Yoshimura, A. Mori, and H. Hara, 1998: High sulfate and nitrate concentrations in precipitation at Nagasaki impacted by long-distant and local sources. Atmos. Environ., 32, 2939-2945.

Jaffe, D., T. Anderson, D. Covert, R. Kotchenruther, B. Trost, J. Danielson, W. Simpson, T. Berntsen, S. Karlsdottir, D. Blake, J. Harris, G. Camichael, and I. Uno, 1999: Transport of Asia Air Pollution to North America. Geophys. Res. Lett., 26, 711-714.

Jaffe, D., I. McKendry, T. Anderson, and H. Price, 2003: Six "new" episodes of trans-Pacific transport of air pollutants. Atmos. Environ., 37, 391-404.

Kato, N., and H. Akimoto, 1992: Anthropogenic emission of SO2 and NOx in Asia: emission inventories. Atmos. Environ., 26, 2997-3017.

Kerminen, V. M., T. A. Pakkanen, and R. E. Hillamo, 1997: Interactions between inorganic trace gases and supermicrometer particles at a coastal site. Atmos. Environ., 31, 27532765.

Kleinbaum, D. G., L. L. Kupper, and K. E. Muller, 1987: Applied regression analysis and other multivariable methods. PWS-KENT Publishing Company, Boston.

Lin, C. Y., S. C. Liu, C. C. K. Chou, T. H. Liu, C. T. Lee, C. S. Yuan, C. J. Shiu, and C. Y. Young, 2004: Long-range transport of Dust Storms and Air Pollutants to Taiwan.TAO, 15, 759-784.

Lin, P. Y., 2002: Characterization of aerosol in metropolitan Taipei during yellow-sand periods. Master thesis, Inst. Environ. Engin., Nat. Central Univ., Chungli, Taiwan, 58-129.

Liu, S. C., and C. J. Shiu, 2001: Asia Dust Storms and Their Impact on the Air Quality of Taiwan. Aerosol Air Qual. Res., 1, 1-8.

Liu, X., N. Gao, P. K. Hopke, D. Cohen, G. Bailey, and P. Crisp, 1996: Evaluation of spatial patterns of fine particle sulfur and lead concentrations in New South Wales, Australia. Atmos. Environ., 30, 9-24.

Ma, C. J., M. Kasahara, R. Holler, and T. Kamiya, 2001: Characteristics of single particles sampled in Japan during the Asian dust storm period. Atmos. Environ., 35, 2707-2714.

Matsumoto, K., and H. Tanaka, 1996: Formation and dissociation of atmospheric particulate nitrate and chlorine: an approach based on phase equilibria. Atmos. Environ., 30, 639648.

Matsumoto, K., I. Nagao, H. Tanaka, H. Miyaji, T. Iida, and Y. Ikebe, 1998: Seasonal characteristics of organic and inorganic species and their size distributions in atmospheric aerosols over the northwest Pacific Ocean. Atmos. Environ., 32, 1931-1946.

Ozeki, T., K. Kiode, and T. Kimoto, 1995: Evaluation of sources of acidity in rainwater using a constrained oblique rotational factor analysis. Environ. Sci. Technol., 29, 1638-1645.

Park, J., and S. Y. Cho, 1998: A long range transport of SO2 and sulfate between Korea and East China. Atmos. Environ., 32, 2745-2756.

Perry, K. D., T. A. Cahill, R. C. Schnell, and J. M. Harris, 1999: Long-range transport of anthropogenic aerosols to the National Oceanic and Atmospheric Administration baseline station at Mauna Loa Observatory, Hawaii. J. Geophys. Res., 104, 18521-18533. 
Prospero, J. M., D. L. Savoie, and R. A. Arimoto, 2003: Long-term record of nss-sulfate and nitrate in aerosols on Midway Island, 1981-2000: Evidence of increased (now decreasing ?) anthropogenic emissions from Asia, 108, article no. 4019, 2003.

Prospero, J. M., and D. L. Savoie, 1989: Effect of continental sources on nitrate concentrations over the Pacific Ocean. Nature, 339, 687-689.

Riley, J. P., and Chester, R., 1971: Introduction to Marine Chemistry, Academic Press, London and New York, 81p.

Shine, K. P., and P. M. D. Forster, 1999: The effect of human activity on radiative forcing of climate change: a review of recent developments. Glob. Planet. Change, 20, 205-225.

Sievering, H., J. Boatman, E. Gorman, Y. Kim, L. Anderson, G. Ennis, M. Lurian, and S. Pandis, 1992: Removal of sulphur from the marine boundary layer by ozone oxidation in sea-salt aerosols. Nature, 360, 571-573.

Talbot, R. W., J. E. Dibb, B. L. Leffer, J. D. Bradshaw, S. T. Sandholm, D. R. Blake, N. J. Blake, G. W. Sachse, J. E. Collins, B. G. Heikes, J. T. Merrill, G. L. Gregory, B. E. Anderson, H. B. Singh, D. C. Thornton, A. R. Bandy, and R. F. Pueschel, 1997: Chemical characteristics of continental outflow from Asia to the troposphere over the western Pacific Ocean during February-March 1994: Results from PEM-West B. J. Geophys. Res., 102, 28255-28274.

Tanner, R. L., B. P. Leaderer, and J. D. Spengler, 1981: Acidity of atmospheric aerosols. Environ. Sci. Technol., 15, 1150-1153.

Terada, H., H. Ueda, and Z. F. Wang, 2002: Trend of acid rain and neutralization by yellow sand in east Asia - a numerical study. Atmos. Environ., 36, 503-509.

Tsunogai, S., and T. Kondo, 1982: Sporadic transport and deposition of continental aerosols to the pacific ocean. J. Geophys. Res., 87, 8870-8874.

Xiao, H., G. R. Carmichael, and J. Durchenwald, 1997: Long-range transport of SOx and dust in East Asia during the PEM B Experiment. J. Geophys. Res., 102, 28589-28612.

Ye, J. R. 2002: The influence of Asian dust storms on acidic air pollutants in Central Taiwan. Master thesis, Inst. Environ. Engin., Nat. Chung-Hsin Univ., Taichung, Taiwan, 1-99.

Young, C. Y., K. H. Lee, and C. M. Liu, 1997: A comparison of air-quality data obtained during a dust-storm event and a local pollution episode-march 12 16,1995.J. Environ. Prot. Soc. ROC, 20, 1-38.

Zhuang, H., C. K. Chan, M. Fang, and A. S. Wexler, 1999: Formation of nitrate and non-seasalt sulfate on coarse particles. Atmos. Environ., 33, 4223-4233. 